\title{
Marketing Religion: The Marketing and Islamic Points of View
}

\author{
Morsy Sahlaoui', Neji Bouslama² \\ ${ }^{1}$ Department of Multimedia IT, Higher institute of Multimedia Arts, Manouba University, Manouba, Tunisia \\ ${ }^{2}$ Faculty of Economics and Management Sciences, Marketing Research and Applications Research Unit, \\ Tunis, Tunisia \\ Email: morsysah@yahoo.fr
}

Received 26 February 2016; accepted 17 April 2016; published 21 April 2016

Copyright @ 2016 by author and Scientific Research Publishing Inc.

This work is licensed under the Creative Commons Attribution International License (CC BY). http://creativecommons.org/licenses/by/4.0/

\section{(c) (i) Open Access}

\begin{abstract}
The purpose of the present paper is to study the possible application of marketing to promote religion in the specific case of "Islam". In fact, marketing techniques have been adapted to religious goals since the beginning of the 19th century. But with the rise of the secularization movements in the post-modern era, its application becomes vital to guaranty the survival of religions notably in the Christian case. Islam is facing the same difficulties, such as the decrease of mosque attendance, the decrease of religious commitment, xenophobia and Islamophobia. Our approach was to study marketing application such as defining the 4P's for the religion of Islam. This would be done based on marketing science and the Islam's sources: The Holly Quran and Prophet Mohamed (PBUH) Hadiths. In the case of Islamic religion's sources, and specially in Holly Quran and Prophet Mohamed (PBUH) Hadiths we found many similarities with marketing strategy notably in the choice of promotional variables and the insistence on the importance of religious promotion or Islamic Daawah. So we suggest that the use of marketing techniques is possible and would have two major purposes: Developing Islamic religiousness and repositioning Islam's image as an opened, tolerant and modern religion.
\end{abstract}

\section{Keywords}

Marketing, Religion, Secularization, Consumer Culture, Christianity, Islam

\section{Introduction}

The success of marketing techniques in commercial and trading fields inspired specialists to extend it to other fields especially in non benefit organizations and social causes. In fact, since their well known article "Broadening the Concept of Marketing", Kotler and Levy [1] were the first marketers to propose the possible extension of 
marketing to social causes. In this context these authors stated that marketing science could be broadened to include non business activities.

This success has inspired even religious institutions. Indeed, marketing techniques have been applied to religion and specifically by churches [2] [3]. In fact, having a well-defined hierarchical structure and specific religious and financial goals, this type of organization has not been difficult to adapt this management specialty [4]. The main promise is the spiritual satisfaction and soul salvation. In this context, based on marketing's principle wish is the development of profitable exchange between the different parties [1] [5] [6], religious organizations such as churches and sects adapt marketing techniques to extend their audiences and consequently their financial resources based on donations.

On the other hand the craze for marketing use in religious promotion is impacted by the rise of materialism and religious disengagement, so religious organizations such as churches were forced to use the marketing techniques [2]. This same trend has affected other important religions in the world especially in the case of Islam, which has suffered since the colonial era several efforts of secularization and the proliferation of Islamophobia due to historical and political events [7]. To this end, we proposed the following research question: Marketing notably with its operational strategy (Marketing Mix) has helped religious organizations like Christian churches to resist and adapt to trends of secularization and religious disengagement; can this discipline be applied to Islam?

This question in the case of the religion of Islam is legitimized especially with additional negative factors such as its declining image due to increasing international and Islamophobia. So, what would be the point of view of Islam? What would be the goals of using marketing? What would be then the Marketing-Mix structure?

To answer these questions relating to the application of marketing to Islam we will treat the following points:

-We begin by introducing the concept of religion and religiosity.

- Then we present the factors that encouraged the emergence of the concept of marketing religion.

- We then present Islam and what the main challenges it faces.

- Finally, we explore the point of view of Islam in the Holly Quran and the Hadith (Prophet's Mohammad PBUH Actions and Recommendations) on the idea of marketing religion and develop the main objectives of the adaptation of marketing techniques.

\section{Religion and Religiosity}

\subsection{What Is a Religion?}

According to Edward Taylor (1871) in his well known work "Primitive culture" religion is the belief in spiritual beings. Going in the same direction reference [8] describes religion as a set of shared beliefs and actions directed to supernatural forces (p. 2).

From the perspective of anthropology reference [9] defines religion as a system of symbols which act to establish powerful and permanent minds and motivations states in humans (p. 90).

From the point of view of sociology, religion is seen as the belief in agents or super natural forces ([10], p. 45). This orientation in the definition of religion is strongly influenced by the Judeo-Christian traditions which give much importance to the concept of belief. This idea is also shared by Islam [11].

Marketing research was also interested in the phenomenon of religion. Thus, reference [12] defines religion as belief in god accompanied by the commitment to follow the principles believed dictated by him (p. 110). reference [13] speak about a belief system that focuses on the super natural, the spiritual, to God and the behavior of the human being as a creature of God on earth and recommended behavior (p. 65).

The diversity of definitions that have been proposed to define the concept of religion indicates that there is no consensus on a general sense to this word [14]. However, faced with all these definitions, we can see that religion can be described as a set of recommended attitudes and behaviors that aim to approach the deity worshiped. Reference [15] states that religion, impacts the behavior of the individual in distinct ways. It has an indirect influence through the membership groups. Religion also introduces a social system that instills in the individual specific beliefs and pushes specific behaviors.

\subsection{What Is Religiousness?}

Religiousness or religiosity is often used to indicate "an individual's conviction, devotion, and veneration 
towards a divinity” $[16]$ (p. 1654).

More over spirituality a very close concept has been used to defined as "One's transcendent relationship to some form of higher power" [17] (p. 415). Generally, in its most comprehensive use, religiosity can encapsulate all dimensions of religion, yet the concept can also be used in a narrow sense to denote an extreme view and over dedication to religious rituals and traditions.

Religion, religious beliefs and religiousness are regressing whether you are in the post-modern Western society or in a more traditional society. Thus, in modern or emergent countries, the trend of secularization of the gods, in favor of the human experience, is dominant [11].

\section{Postmodern Disintegration of Faith and the Emergence of Marketing Religion}

Based on previous works on the desecration and disintegration of religion in postmodern world, reference [2] enumerates several factors generating the current loss of faith and importance of religion in individual's lives: secularization and religious norms disintegration rise of consumer culture and proliferation of individualism.

\subsection{Secularization Movements and Religious Norms and Values Disintegration}

According to The American Heritage dictionary (2000) [18] secularism is the idea that religious rites values and observance should be excluded from politics, civil affairs or public education.

For Max Weber as the precursor of the theory of secularization [19], secularization leads to loss of interest in religion. Moreover, the secularization thesis argues the abandonment of religion by the decline of religious practices and its significant diminishing for the occidental social system [20]. Also secularization leads to the change of religious discourse that was forced to change to crop requirements of consumer movements to avoid being marginalized [3]. In addition to the emergence secularization movements, the concept of consumer culture increased the perception of religion as a product similar to other goods or services provided by the market [2] [3].

Secularization in occidental cultures reflects a shift away from religion and consecration of materialism [19]. Thus, the movement of secularization notably in the Christian context tends to desecrate the sacred represented by religion and to consider sacred the secular [3]. Moreover Secularization as a social movement has generated a political movement that advocates secularism by the separation of politics from religion [21].

The trend of secularization in Europe and France specifically rises in the context of the conflict with the church whose representatives committed many injustices in the name of the Lord [22]. All these facts leads to the fragmentation of religious life and abandonment of religious values and norms since the 1960s wish weakened the religion's social importance and role in daily life individuals [23].

\subsection{Consumer Culture}

Moreover, the process of modernization has resulted in the emergence of the consumer culture, which by its diffusion has participated in the movement of desecration of sacred religious [24]. This culture of consumption took an important extent it has developed its own sacred symbols, often exploiting religious beliefs [24] [25].

In the same context references [24] [25] speak about the resulted sacredness of consumer products from the technological development and reflecting a style of modern western life. They link it to the desecration or the secularization of religion, tradition and specific practices and its replacement by new sacred symbols. This would lead to the fact that consumer culture unlike other forms of culture, replaces the achievement of religious goals by seeking satisfaction of needs through consumer goods.

This trend has been recently checked in America, the birthplace of the consumer culture. In fact, the results of the study on the "U.S. Religious Landscape (2008)" [8] of "Pew Centre Research" stated that the most influential American churches are in the process of losing their followers. The same trend is true in Australia and in other Catholic countries; it is checked in particular among young people. Indeed, young people aged 15 to 29 years represent only $14 \%$ of true churches [26].

\subsection{Rise of Individualism}

The proliferation of individualism, protecting individual freedom and autonomy in postmodern society is fundamentally against social and religious institutions rules [23] [27]. In fact, religious beliefs, notably in monothe- 
istic religions, prone collectivism and interest for other people well-being in the same society [28]. Actually the tendency is the rejection of traditional religious values in favor of the individualistic secularized ones, such as self fulfillment instead of collectivism and religiosity [29]-[31].

\section{Religious Disintegration in the Muslim World}

As part of most practiced religions Islam suffers from secularism, consumerism, individualism but also Islamophobia.

\subsection{Secularism in Islamic World}

The consumer's culture making sacred consumption has also spread in Muslim countries through the acculturation process that takes place in a direct and indirect contact in the context of globalization, this trend was strengthened by a favorable colonial heritage [7]. Indeed, after the period of colonization and following different trends of modernization several Muslim countries including Tunisia, Algeria, Egypt and Turkey are experiencing a strong trend towards secularization and disengagement toward Islam's rules and values [7] [20]. This trend is observed especially among the Arab elite and the North African elite in particular [32]. Secularism also known in France as "Laïcité" whish goal is defending political and social relations from their perceived Islamic hegemony was used by the colonizers to suppress Tunisian independence movements [22]. Indeed during the post-colonial period experienced by the Arab countries, there have been two major roles played as well by the westernized elite and Islamic religion [33]:

-The first actor which is the westernized elite, focused on the economic and social development by drawing on experience from other Western secularism.

-The second actor is Islam playing a fundamental role in the political and cultural resistance to the European acculturation. Hence the suspicion those Western governments can develop against Islamist movements.

\subsection{Islamophobia}

In addition to the trends of secularization and the dissemination of the culture of consumption and secular political trends to diminish the commitment to Islam, the religion faces another major problem which is the rise of fundamentalism and neo-fundamentalism [33]. This fact was one of the most important roots of Islamophobia.

Etymologically, the word Islamophobia is the combination of the word Islam and the suffix "Phobia". The suffix Phobia derivate from the Latin word Phobos that means fear (Oxford English Dictionary) [34]. In social psychology it refers to an unreasonable fear of an object, a situation or a subject perceived as a danger that generates an anxiety and avoidance [35].

Looking in the "Oxford English Dictionary" [34], Islamophobia means "Intense dislike or fear of Islam, esp. as a political force; hostility or prejudice towards Muslims". This word is attested to in English as early as 1923.

Islamophobia is often confused with Anti-Arabism that is consistent with hostility and discrimination toward Arabs notably in European and North American countries. The confusion is from the fact that the majority of Arabs in Arab countries are Muslims [36].

Reference [37] speaks about Islamophobia as a fear of Muslims and Islam; a rejection of the Muslim religion; or a form of different racism.

Moreover, some Islamophobia trends exhibit bipolar worldview stating that modernity is pure product of the secular West, while archaic and fanaticism comes from Islam [36] [38].

Although marketing research is often interested in religion, considering it as an independent variable and trying to understand its effect on consumer behavior [3], some research has focused on the marketing of religion [2] [3]. In this case, marketing science and techniques are used to promote certain religious doctrines, concepts, behaviors and ancillary specific products [39].

Indeed, the use of marketing's means and techniques such as Marketing-Mix development, in the service of religion is not new. When they first appear, printed media and advertising were adopted to sell Bibles [3]. Much more recently, with the emergence of postmodern context and the secularization of religion the use of marketing techniques become necessary. According to the theory of secularization, most companies engage in industrialization and the creation of wealth, the greater their interest to religion decreases [3].

Thus, we note that Islam, more than Christianity, faces two major obstacles, secularization which considers 
somewhere that religion is obsolete and fundamentalism that distorts Islam to make it rigid and threatening.

If to face the disinterestedness to faith, churches have adopted the principles of marketing, such as segmentation, targeting and tailoring of speech, we believe that Islam can just do so by adapting marketing techniques to improve its image and to develop the level of religiosity among Muslims.

\section{Marketing Religion, the Case of Islam}

Due to all the Modern and postmodern social mutation that affected religions, churches and religious organizations are now managed such as a firm where the product is salvation and spiritual wellbeing [40]. In the particular context of faith, a real religious market (Hinduism, Buddhism, Chinto Cults, Puritan Christian Sects) has emerged all over the world and specially in America since 1776 [41]. So as part of this highly competitive market, the use of marketing strategies had a great contribution to the development of religious organizations and churches [42]. Christianity and other religions has thus developed new orientations such as repositioning in a more flexible image than previous movements characterized by their fundamentalist and traditionalist values and rules. Can Islam adopt the same strategy?

\subsection{Marketing Christianity as Example}

Christianity is based on two fundamental tenets: the Incarnation and the Trinity [43]. The incarnation means the oneness of god and Jesus in the same person [44]. Christianity is also one of the three monotheistic religions, where Trinity the main characteristic, which means that one God is revealed in three distinct forms. Christianity has no requirements, Jesus gave directives and general guidelines but they do not specify in rituals [45].

Moreover, adopting the new marketing spirit, evangelism has emerged as a religious movement that has adopted a new strategy by relaxing their moral discourses and reducing practices. In fact, social marketing as the principle source of religious marketing, is defined as "the use of the principles and marketing techniques to influence a target to accept, reject, modify or voluntarily abandon a behavior for the benefit of individuals, groups or society as a whole" [5] (p. 5). Also, the role of social marketing can extend to change knowledge and beliefs [1] [5].

In this context, reference [46], stated that this discipline can play an important role for religious institutions to promote for example Christianity and increase the number of faithful churches.

Thus, marketers develop marketing strategies and mix concentrated on spiritual beliefs and behavior changes [5] [47] [48] by:

- Developing the interest to the needs and believes of the targeted people wish is one of the fundamental principles of classical marketing.

- Just like in the classic marketing religious marketing must proceed to studying the principle expectations and problems of the targeted population,

- The segmentation of the market and the choice of the targeted segment by comparing the potential of the latter to the objectives of the organization.

- Finally the development of religious mix.

So, in the context of faith marketing, marketing techniques are used to influence individuals to change their behavior toward religion by being respectful to religious guidance, rules [49].

To this end, there are behaviors that are highlighted and promoted [2] [40]:

- Adherence to organized religious groups.

- The maintenance or increase loyalty to the religion.

- Increase the level of religiosity.

- Confidence in religious belief.

- Contribute financially to the religious organization.

To be more effective, churches developed their proper vision of Marketing Mix.

After seeing the objectives of marketing in relation to Christianity, what should be the objectives of the application of marketing for Islam?

\subsection{Marketing Islam}

Islam is one of the three monotheistic religions; it is practiced by over a billion and a half people (according to 
the Pew Research Center in 2009: 1.57 billion people). Islam means entire sub mission and voluntary allegiance to Allah the only one god and creator.

Islamic law called "Sharia" contains requirements that are in many cases similar to that of the Judeo- Christian law [45]. Islam is interested on the individual behavior and attitudes through the establishment of a line of conduct specified by the Koran and the Hadith which are the main sources of legislation.

Thus, there are forbidden (Haram), legal (Halal), the tolerated (Makrooh) and recommended (Mandoub) behaviors and attitudes. Islam has contributed to the formation of a specific culture encompassing specific standards and values that are shared by the majority of companies and it is the dominant religion [57].

Moreover, Islam has also undergoes the first effect of the colonial force and the dissemination of the culture of consumption which increased the tendency towards materialism and away from religion. Unfortunately, Islam is often seen as a religion that hinders freedoms and represses the energies [50].

Islam is also perceived as a religion that is scary [50], this fear is old it is even part of the European identity [4], this fear also affects the westernized elite in the Arab countries. This tendency is accentuated after the various attacks in recent decades and the emergence of some threatening fanatical groups.

From this perspective we can say that the main challenges of marketing Islam strategies would be the rise of the level of religious commitment for Muslims, the change of the actual image that frightens not only Western but also Muslim societies and the development of a Marketing Mix strategy for Islam.

\subsubsection{Developing Religiousness for Muslims}

At the individual level religion is based on the degree of adhesion of the individual to specific religious values and standards, this variable are also called religiosity [51] Going in the same direction, reference [52] defines religiousness as the degree to which the individual adheres to religious values, beliefs and practices and specific uses in his everyday life (p. 85).

This variable can be equated with the term "Iman" in Islam which means total acceptance of the Muslim faith which contains characteristic values, norms and actions. In this context, the belief and practice are closely related; however, there are several degrees of believers.

Here we find the Islam's meaning of believing, in fact, the Holly Quran say: "This is the Book about which there is no doubt, a guidance for those conscious of Allah-(2) who believe in the unseen, establish prayer, and spend out of what we have provided for them, (3) and who believe in what has been revealed to you, [O Muhammad], (4) and what was revealed before you, and of the Hereafter they are certain [in faith]" (The Cow 2-4).

According to the Hadith of the Prophet Mohammad PBUH in Sahih Al-Bukhârî, and in Sahih Muslim [53] (p. 20), Islam is built on five pillars:

- The Chahadataïn ("Statement of faith") "I testify that there is no true god except Allah and that Muhammad is His messenger."

- The Salat, the fulfillment of daily prayer.

- The charity towards the needy, Zakat.

- Respect of fasting during Ramadan.

- The hajj, the pilgrimage to Mecca at least once in his life, if we have the materials and physical means.

We can see clearly that the main components of Muslim faith are: believing, prying and being good and charitable toward others.

In this context we can maintain the same strategic targets in terms of developing individual's identification to Islam as in the case of Christian Religion as stated by reference [40] and reference [2]. To this end we can use the same church marketing strategic orientations [5] [48] and adopt them to Islam's situation, mainly by focusing on the needs of Muslims population in terms of faith, texts analysis and knowledge to counter the fanatic and extremist trends.

\subsubsection{Changing Opinions about Islam}

Referring to the Holly Quran we can find many verses that indicate the necessity of having some persons whose role is to invite people to know about Islam's values and virtues. "And let there be [arising] from you a nation inviting to [all that is] good, enjoining what is right and forbidding what is wrong, and those will be the successful" (Quran, surat: Ali Imran (104)). This role is extremely important in the actual context with the rise of extremism and radicalism and the emergence of fanatic movement such as Al Qaida and ISIS clearly affecting the real peaceful image of Islam. 
Moreover the rise of Islamophobia in America and in Europe is clearly menacing Muslims integration in host cultures. In France in 2012 Ifop institute made a survey on 1736 persons representing the French population and aged more than 18 years. The survey revealed that French people have already a reinforced negative image of Islam. In fact, $43 \%$ of the people in the sample consider Islam as a "Menace", $60 \%$ consider this religion more and more "important". As explanation of their fear, French people justify their negative attitudes by justifications as: refusal of integration in the French society and culture (68\%), big cultural differences (52\%). When asked about the global Islam's image the respondents chose largely the item "Rejection of occidental values".

\subsubsection{Islamic Religion and the Marketing Mix}

By a simple search in the principle texts of Islam that are the Holly Quran and the Hadith we can find that Islam focuses on the same strategic marketing-mix domains.

\section{1) The first P: Islam}

In the social marketing field the product can be a behavior, a belief or an idea that you want to promote [54]. In the case of Islam, the main subject of promotion is its specific good behaving with others and following what is universally right and the refusal of what is universally wrong. So we can find these verses of the Quran:

- "You are the best nation produced [as an example] for mankind. You enjoin what is right and forbid what is wrong and believe in Allah. If only the People of the Scripture had believed, it would have been better for them. Among them are believers, but most of them are defiantly disobedient" (Quran, surat: Ali Imran (110)).

Moreover, reference [2] state that in religious product policy marketers could focus on expectations such as salvation eternal life or enjoyment of celestial happiness. In the Holly Quran we can find many verses speaking about the rewards of Muslim believers such as:

- Indeed, those who have said, "Our Lord is Allah, and then remained on a right course-there will be no fear concerning them, nor will they grieve (13) Those are the companions of Paradise, abiding eternally therein as reward for what they used to do (14)" (Quran, surat: Al Ahquaf 13-14).

It is clearly mentioned that Islam is the only whey of salvation by good behaving with mankind. In fact for Ibno-Kathir transliteration, those who say: "Our Lord is (only) Allah," and thereafter stand firm, on them shall be no fear, nor shall they grieve. More over such shall be the dwellers of Paradise, abiding therein forever. It is so a reward for what they used to do.

- "Alif, Lam, Meem. (1) This is the Book about which there is no doubt, a guidance for those conscious of Allah-(2) (Quran, surat: Al-Baquarah 1-2).

In Ibno-Kathir transliteration we can find that there is no Rayb, means about which there is no doubt in the Book, which is the Qur'an. Additionally, the Qur'an is without a doubt revealed from Allah. In which there is guidance (Similarly, Allah said in Quran Surat As-Sajdah). In this case the main objective is to develop Muslim's religiousness.

For social marketers as reference [6] there is no product that can accomplish changing ideas or adopting good attitudes or behaviors. They state that there must be an effort to "Package the social idea in a manner which their target audience find desirable” ( $p$ 7) and are willing to adopt it. This task must be preceded by the study of Muslims needs in this field and Muslims and non Muslims attitudes toward Islam. For Kotler and Zaltman [6] marketers must innovate to influence positively targeted people starting from knowing their faith and religious needs and aspirations.

\section{2) The second P: The price}

In social marketing and marketing to nonprofit organizations, price isn’t a question of money but it is question of involvement and commitment [55]. In the social marketing literature, price refers to what will it cost a person to stop or take on a certain behavior or attitude [55] [56].

Islam dos not demand any price for being a Muslim. In Islam there are no ancillary products like in other religious organizations and sects. Moreover the notion of price in Islam is completely reversed in fact the Holly Quran says:

- "Surely Allah has purchased of the believers their lives and their belongings and in return has promised that they shall have Paradise...” (Quran, surat: Tawba 111).

So we can understand from this verse that the transaction is simple: total surrender and obedience to Allah and in return believer receive forgiveness and eternal life in paradise. 
- "Believers, shall I direct you to a commerce that will deliver you from a grievous chastisement? (10) Have faith in Allah and His Messenger 15 and strive in the Way of Allah with your possessions and your lives. That is better for you if you only knew (11)" (Quran, surat: As-Saff).

The price in this context is largely psychological it consists in breaking certain bad habits and adopts others perceived as good and commendable [6].

\section{3) The third P: The promotion}

For social and nonprofit organizations marketers, promotion is all advertising actions done by responsible of the "product" diffusion. In this context the holly Quran insists on the role of individual i.e. the Muslims to promote their religion:

- And who is better in speech than one who invites to Allah and does righteousness and says, "Indeed, I am of the Muslims." (Quran, surat: Fussilat (33)).

In the holly Quran there are specific instructions indicating the best way to invite people to Islam.

- "Invite to the way of your Lord with wisdom and good instruction, and argue with them in a way that is best. Indeed, your Lord is most knowing of who has strayed from His way, and He is most knowing of who is [rightly] guided." (Quran, surat: An-Nahl 125).

The holly Quran indicates that the "Daawah" or the invitation to Islam is the duty of all Muslims.

- Say, "This is my way; I invite to Allah with insight, I and those who follow me. And exalted is Allah; and I am not of those who associate others with Him" (Quran, surat: Yusuf (108)).

- "And bear patiently the vain things they utter, and gracefully forsake them." (Quran, surat: Al Muzzamil 73: $10)$.

For Ibnou-Kathir transliteration "gracefully forsaking them" does not mean to abandon calling them to Islam; it rather means to graciously disregard their comments by not responding with the like and most importantly to pray that Allah guides them.

Moreover in Prophet's Mohammed PBUH "Hadith" we can find similar instructions and encouragements to Muslims to preach or to do Daawah:

- "If Allah guides a person through you, it is better for you than all that is on the earth" [57] (p. 94).

- "One who guides to something good has a reward similar to that of its doer" [58] (Book 20, n. 4665).

From all these references we can say that in Islam the most important component of religious promotion and communication is the individual. But this strategy is effective only if the individual reflects the good image of this religion. By displaying act of tolerance and peacefulness exactly as it is said in the Quran. Moreover all what do "ISIS" in terms of assassination, mass destruction, historical sites destruction and propaganda, does only raise hatred and Islamophobia toward Muslims.

\section{4) The forth P: The place}

The review of the literature concerning this "P" speaks about the diffusion and the barriers that we must fight to make our "product" present where the targeted people needs it [6] [55] [56]. For this component we thought about Muslims places of worship "The Mosques".

In this context Prophet’s Mohammed PBUH "Hadith” speaks about building and maintaining Mosques:

Uthman Ibn Affan reported: The Messenger of Allah, peace and blessings be upon him, said, "Whoever builds a mosque for Allah, then Allah will build for him a similar house in Paradise.” (Sahih Muslim, 533) [59].

This Hadith rewards those who build, maintain and take care of mosques. The reward will be a house in paradise

Moreover, it was reported that the Prophet Muhammad PBUH said: "Whoever eats garlic, onion, then keep away from our Masjid because the angels get offended from what offends the children of Adam." (Sahih Muslim Book 4 number 1143) [58].

Umar Ibn Al-Khattab (RAU) used to say while he on the Minbar: "I saw the Prophet Muhammad (SAW) when He found their smell (garlic, onion) from a man in the Masjid, he ordered him to be taken out". and Umar Ibn Al-Khattab (RAU) said: "If you must eat them, then cook them well." (Sahihu Muslim) [58].

The place of the mosque is important in Islam. In fact Quran warned all who does not respect mosques attendance rules and ethics.

"And who are more unjust than those who prevent the name of Allah from being mentioned in His mosques and strive toward their destruction. It is not for them to enter them except in fear. For them in this world is disgrace and they will have in the Hereafter a great punishment?” (Quran, surat: Al Baqara 114) 
All these ideas for Islamic Mix are made to explore different ways to develop Muslims religiousness and help to diffuse good Islamic attitudes and behaviors.

\section{Conclusions}

By studying the factors that have promoted the use of marketing to develop Christianity, we find that Islamic religion faces the same problems such as the religious disengagement. This is due to secularization and the spread of consumer culture that has replaced some sacred religious symbols by other ones associated with individual well-being and hedonic consumption. We also showed that the Muslim religion was facing not only seculari- zation but also the rise of neo-fundamentalism which promoted the growth of Islamophobia. Thus, we can say that marketing can have, as in the case of Christianity, a great contribution to Islam.

The Christian religious institutions have chosen several goals such as developing religious commitment and donations to fund their churches. In the case of Islam, marketing can be a great contribution in the development of religiosity through the promotion of religious behavior and beliefs. Moreover, this study shows that marketing components are consistent with recommendations in the most sacred sources of Islam: Holly Quran and Prophet Mohammed PBUH Hadith.

As a recommendation, marketing can be used to change negative perceptions diffused especially in western countries and westernized local Muslim elite groups based on fear from the rise of neo-fundamentalism and radicalism. Islamic religion is managed in Arab and western countries by ministries of religious affairs so marketing strategies and techniques can be used by these government institutions and Muslim religious organizations and associations to develop religiousness by diffusing the appropriate message.

Furthermore, this research is a conceptual proposition to extend religious marketing principals to Islam promotion. Further ground experimentations and researches are required to propose efficient marketing actions to promote Islam. Indeed, this work can be deepened through the study of the effect of certain communication and promotion techniques on religiosity, such as advertising.

Finally, we suggest a future research that would have an objective to explore the effect of marketing communication techniques in order to change the actual bad perceived image of Islam. This would be by searching real Islamophobia causes and by testing and adopting specific communication strategies.

\section{References}

[1] Kotler, P. and Levy, J.S. (1969) Broadening the Concept of Marketing. Journal of Marketing, 33, 10-15. http://dx.doi.org/10.2307/1248740

[2] Usinier, J.C. and Stolz, J. (2014) Religions as Brands: New Perspectives on the Marketization of Religion and Spirituality. Ashgate Publishing Limited, Routledge.

[3] Einstein, M. (2008) Brands of Faith Marketing Religion in a Commercial Age. Ed Routeledge, London and New York.

[4] Santoro, A. and Siliman, D. (2015) Religion and the Marketplace in the United States. Oxford University Press, Oxford.

[5] Kotler, P., Roberto, N. and Lee, N. (2002) Social Marketing: Improving the Quality of Life. Sage Publications, Thousand Oaks.

[6] Kotler, P. and Zaltman, G. (1971) Social Marketing: An Approach to Planned Social Change. Journal of Marketing, 35, 8-12. http://dx.doi.org/10.2307/1249783

[7] Tamimi, A. (2002) The Origins of Arab Secularism. In: Tamimi, A. and Esposito, J.L. Eds., Islam and Secularism in the Middle Limited, Chapter 2, New York University Press.

[8] Whitehouse, H. (2004) Modes of Religiosity: Of Cognitive Theory of Religious Transmission. Altamina Press.

[9] Geertz, C. (1973) The Interpretation of Culture. Basic Books, New York.

[10] Goody, J. (1961) Religion and Ritual: The Definitional Problem. The British Journal of Sociology, 12, 142-164. http://dx.doi.org/10.2307/586928

[11] Swatos Jr., W.H. (1998) Encyclopedia of Religion and Society. Altamira Press.

[12] McDaniel, S.W. and Burnett, J.J. (1990) Consumer Religiosity and Retail Store Evaluative Criteria. Journal of the Academy of Marketing Science, 18, 101-112. http://dx.doi.org/10.1007/BF02726426

[13] Sheth, J.N. and Mittal, B. (2004) Customer Behavior: A Managerial Perspective. 2nd Edition, South-Western, USA.

[14] Mokhlis, S. (2009) Relevancy and Measurement of Religiosity in Consumer Behavior Research. International Business Research, 2, 75 -84. http://dx.doi.org/10.5539/ibr.v2n3p75 
[15] Greeley, A.M. (1963) A Note on The origins of Religion Differences. Journal for The scientific Study of Religion, 3 , 21-31. http://dx.doi.org/10.2307/1385003

[16] Gallagher, S. and Tierney, W. (2013) Encyclopedia of Behavioral Medicine. Ricks J Editions, Springer, New York.

[17] Thoresen, C.E. (1998) Spirituality, Health, and Science. The Coming Revival? In: Roth-Roemer, S., Kurpius, S.E.R. and Carmin, C.N., Eds., The Emerging Role of Counseling Psychology in Health Care, W. W. Norton, New York, 409-431.

[18] The American Heritage (2000) Dictionary of the English Language. 4th Edition, Houghton Mifflin Company, Turtleback.

[19] Tschannen, O. (1992) Les théories de la secularization. Librairie Droz, Genève.

[20] Wilson, B. (1998) Secularization Thesis: Criticism and Rebuttals. In: Laermans, R., Wilson, B.R., Dobbelaere, K. and Billiet, J., Eds., Secularization and Social Integration: Papers in Honor of Karel Dobbelaere, Chapter 6, Leuven University Press, Leuven, 45-65.

[21] Charon, A. (1996) Religion, Secularism, Modernity Francophone Experiences in North America. Press of the University Laval, Québec City.

[22] Abidi, L. (2000) Secularism: Misunderstandings and Representations. Mediterranean Confluence, No. 32, 35-41.

[23] Brown, L.S. (1993) The Politics of Individualism: Liberalism, Liberal Feminism, and Anarchism. Black Rose Books, Montreal.

[24] Belk, R.W., Wallendorf, M. and Sherry Jr., J.F. (1989) The Sacred and the Profane in Consumer Behavior: Theodicy on the Odyssey. Journal of Consumer Research, 16, 1-38. http://dx.doi.org/10.1086/209191

[25] Belk, R.W. (1989) Materialism and the Modern U.S. Christmas. In: Hirschman, E.C., Eds., Special Volumes—Interpretive Consumer Research, Association for Consumer Research, Provo, 115-135.

[26] Davis, T. and Yip, J. (2004) Reconciling Christianity and Modernity: Australian Youth and Religion. Advances in Consumer Research, 31, 113-117.

[27] Triandis, H.C. (2001) Individualism-Collectivism and Personality. Journal of Personality, 69, 909-914. http://dx.doi.org/10.1111/1467-6494.696169

[28] Cohen, A.B. and Hill, P.C. (2007) Religion as Culture: Religious Individualism and Collectivism among American Catholics, Jews, and Protestants. Journal of Personality, 75, 709-742. http://dx.doi.org/10.1111/j.1467-6494.2007.00454.x

[29] Hastings, G. (2007) Social Marketing: Why Should the Devil Have All the Best Tunes? Elsevier Ltd, Amsterdam.

[30] Hastings, G., Angus, K. and Bryant, C. (2011) The SAGE Handbook of Social Marketing. SAGE Publications Ltd, Thousand Oaks.

[31] Hastings, G. (2003) Encyclopedia of Religion and Ethics. Part 11, Kessinger Publishing, Whitefish.

[32] Ben Elmostafa, O. (2006) The Islamic Movement in Morocco: Their Modes of Action and Organization. L’Harmattan, Paris.

[33] Akgüngör, Ç. and Bayraktar, S.U. (2005) Secularization, Democratization and Muslim World: Change Process. Cahiers d'Etudes on the Eastern Mediterranean and the World Turco-Iranian [Online], 35.

[34] Oxford English Dictionary: -phobia, comb. Form. Oxford University Press, Oxford.

[35] Bourne, E.J. (2011) The Anxiety \& Phobia Workbook. 5th Edition, New Harbinger Publications, Oakland, 50-51.

[36] Echebarria-Echabe, A. and Guede, E.F. (2007) A New Measure of Anti-Arab Prejudice: Reliability and Validity Evidence. Journal of Applied Social Psychology, 37, 1077-1091. http://dx.doi.org/10.1111/j.1559-1816.2007.00200.x

[37] Helbling, M. (2012) Islamophobia in the West: An Introduction. In: Helbling, M., Ed., Islamophobia in the West. Measuring and Explaining Individual Attitudes, Routledge, London, 1-18.

[38] Bistolfi, R. (2000) Islam and Secularism: Golf European. Mediterranean Confluence, No. 32, 7-12.

[39] Mallika, N. (2009) The Eleventh Commandment: An Introduction to Religio-Marketing. Business and Economics, VDM Verlag, Saarbrücken.

[40] Stolz, J. (Ed.) (2008) Salvation Goods and Religious Markets: Theory and Applications.

[41] Iannaccone, L.R., Finke, R. and Stark, R. (1997) Deregulating Religion: The Economics of Church and State, Economic Inquiry. Huntington Beach, 35, 350-365. http://dx.doi.org/10.1111/j.1465-7295.1997.tb01915.x

[42] Cooke, P. (2008) Branding Faith: Why Some Churches and Non Profits Impact Culture and Others Don't. Regal, Ventura.

[43] Durand, A. (2005) Islam at the Risk of Secularism Emergencies and Disruptions. L’Harmattan, Paris. 
[44] De Be'rulle, C. (1884) The Apostle of the Incarnate Word or Elevations on the Magnitudes of Jesus Christ. Paul Mellier, Paris.

[45] Sanson, H. (2008) Islam and Christianity in the Mirror One Another: A Christian Approach to Algeria. L'Harmattan, Paris.

[46] Hellmans, S. (1998) Secularization in a Religious Modernity. In: Laermans, R., Wilson, B.R., Dobbelaere, K. and Billiet, J., Eds., Secularization and Social Integration: Papers in Honor of Karel Dobbelaere, Chapter 7, Leuven University Press, Leuven, 67-82.

[47] Kuzma, A., Kuzma, A. and Kuzma, J. (2009) How Religion HAS Embraced Marketing and the Implications for Business. Journal of Management and Marketing Research, 2, 1-10.

[48] Stevens, R.E., Loudon, D.L., Cole, H. and Wrenn, B. (2012) Concise Encyclopedia of Church and Religious Organization Marketing. Routledge, Taylor and Francis Group, Abingdon.

[49] Sargean, A. and Wymer, W. (2007) The Routledge Companion to Nonprofit Marketing. Routledge, Abingdon.

[50] Al-Uthaymeen, M. (2006) Youth: Problems and Solutions. Editions Anas, Riyadh.

[51] Sood, J. and Nasu, Y. (1995) Religiosity and Nationality: An Exploratory Study of Their Effect on Consumer Behaviour in Japan and the United States. Journal of Business Research, 34, 1-9. http://dx.doi.org/10.1016/0148-2963(94)00015-7

[52] Worthington Jr., E.L., Wade, N.G., Hight, T.L., Ripley, J.S., McCullough, M.E., Berry, J.W., Schmitt, M.M., Berry, J.T., Bursley, K.H. and O’Connor, L. (2003) The Religious Commitment Inventory-10: Development, Refinement, and Validation of a Brief Scale for Research and Counseling. Journal of Counseling Psychology, 50, 84-96. http://dx.doi.org/10.1037/0022-0167.50.1.84

[53] Al-Ani, S.H. and Tel, S.A. (2009) Book of Faith. Islamic Book Trust, Kuala Lampur.

[54] Donovan, R. and Henley, N. (2010) Principles and Practice of Social Marketing: An International Perspective. Cambridge University Press, Cambridge. http://dx.doi.org/10.1037/0022-0167.50.1.84

[55] Herron, D. (1997) Marketing Nonprofit Programs and Services: Proven and Practical Strategies to Get More Customers, Members, and Donors. Jossey-Bass, San Francisco.

[56] Goldberg, M., Fishbein, M. and Middlestat, S. (Eds.) (1997) Social Marketing: Theoretical and Practical Perspectives. The Academy for Educational Development, Washington DC.

[57] Al-Sheha, A. (2013) How Does One Become Muslim. Islam Land, Saudi Arabia.

[58] Sidiqui, A. (1973) Sahih Muslim. Peace Vision.

[59] Nassar As-Salafi, A.H. (2010) Description of Paradisein the Glorius Quran. Darussalam, Riyadh. 